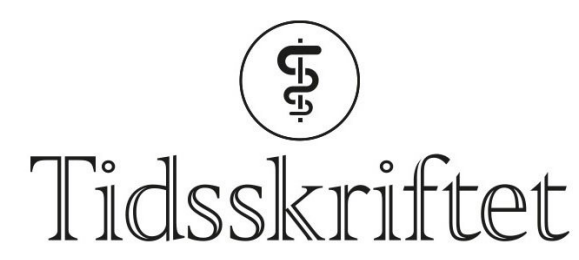

DEN NORSKE LEGEFORENING

\title{
Rettelse: Behandling av akne
}

RETTELSE

KATARINA ZAK STANGELAND

THEIS HULDT-NYSTRØM

XIAOTONG LI

KJERSTI DANIELSEN

Tidsskr Nor Legeforen 2019; 139: 1173-6.

I Tidsskriftet nr. 12/2019 på side 1175 skal siste setning i nest siste avsnitt være:

Isotretinoinbehandling bør vurderes raskt ved arrdannende eller alvorlig nodulocystisk akne samt ved manglende behandlingseffekt etter 2-3 måneder med antibiotika og topikalt retinoid.

Vi understreker at tetrasyklin er kontraindisert ved bruk av isotretinoin på grunn av fare for hjerneødem. Bruk av topikalt retinoid anbefales ikke på grunn av ytterligere uttørring av huden.

$V i$ beklager feilen, den er rettet på nett.

Publisert: 17. september 2019. Tidsskr Nor Legeforen. DOI: 10.4045/tidsskr.19.0592

(C) Tidsskrift for Den norske legeforening 2020. Lastet ned fra tidsskriftet.no 